\title{
Implementation of Exponential Comparison Method in Performance Evaluation of Temporary Employees in District Court of Prabumulih
}

\author{
St Dhiah Raniah NAPIAN ${ }^{1}$ and Allsela MEIRIZA ${ }^{2 *}$
}

\author{
${ }^{1} 09031181621011 @$ students.ilkom.unsri.ac.id, Information System Study Program, Computer Science Faculty of \\ Sriwijaya University Indonesia \\ ${ }^{2}$ allsela@ilkom.unsri.ac.id, Information System Study Program, Computer Science Faculty of Sriwijaya University \\ Indonesia \\ *Corresponding author: allsela@ilkom.unsri.ac.id
}

\begin{abstract}
As an effort of the District Court of Prabumulih in maintaining the quality of its employees, the District Court of Prabumulih routinely evaluates the performance of temporary employees each year. The process of evaluating the performance of temporary employees at the District Court of Prabumulih is carried out by providing an assessment of the performance of temporary employees based on several criteria. The purpose of this study is to implement the Exponential Comparison Method in evaluating the performance of temporary employees in the District Court of Prabumulih. The total value generated using this method shows a range of priorities large enough so that the results of the priority order become clearer. The results show the highest total value is 6566 while the lowest total value is 1668.
\end{abstract}

Keywords: Exponential Comparison Method, performance evaluation, temporary employees

\section{Introduction}

Human resources are important assets and cannot be separated from an organization, both agencies, and companies [1]. An example of agencies in Indonesia is the District Court of Prabumulih. The District Court of Prabumulih is a judicial institution within the general court environment in Prabumulih City. Human resources in the District Court of Prabumulih are divided into two, namely permanent employees and temporary employees. As an effort of the District Court of Prabumulih in maintaining the quality of its employees, the District Court of Prabumulih routinely evaluates the performance of temporary employees each year.

The process of evaluating the performance of temporary employees at the District Court of Prabumulih is carried out by providing an assessment of the performance of temporary employees based on several criteria such as Willingness Learning, Awareness, Discipline, SelfManagement, Communication, Responsibility, Ethics and Behavior. The seven criteria were obtained from the results of interviews with the Head of the Personnel Subdivision and the Administrative Organization of the District Court of Prabumulih. The management of performance evaluation data for temporary employees in the District Court of Prabumulih has not been properly automated so that it produces non-optimal results. This is considered risky because the inaccuracies of the data obtained make the decision making ineffective. Base on the problem, we need a system that can help in evaluating the performance of temporary employees in the District Court of Prabumulih by implementing the Exponential Comparison Method.
The purpose of this study is to implement the Exponential Comparison Method in evaluating the performance of temporary employees in the District Court of Prabumulih. The Exponential Comparison Method is one of the methods in a decision support system that is used to sort alternative priority decisions with multiple criteria. The Exponential Comparison method is used because the resulting score illustrates a large priority sequence so that the priority order of alternative decisions becomes more apparent [2]. By using the exponential calculation, the value of the difference between criteria can be distinguished depending on the ability of the person who is assessing [3].

\section{Literature Review}

\section{Exponential Comparison Method}

The Exponential Comparison Method is one of the methods in a decision support system that is used to sort alternative priority decisions with multiple criteria [4]. The Exponential Comparison Method is a method of decision making that quantifies opinions on a certain range [5]. By using the exponential calculation, the value of the difference between criteria can be distinguished depending on the ability of the person who is assessing [3]. The steps in solving a problem using the Exponential Comparison Method are as follows [2]:

Arrange alternatives to be selected.

Determine the criteria or relative comparison of decision criteria that are important to be evaluated using a certain scale based on the wishes of the decision-maker. 
Determine the relative importance of each decision criterion. Determination of the weight is set on each criterion to indicate the level of importance of a criterion. Assess all alternatives on each criterion in the form of a total score of each alternative.

Calculate the Total Value (TN) of each alternative. The following are the equation of the Exponential Comparison Method:

Total Value $\left(T N_{i}\right)=\sum_{j=1}^{m}\left(R K_{i j}\right)^{T K K_{j}}$

Information:

$\mathrm{TN}_{\mathrm{i}}=$ Total $\mathrm{i}$ alternative value.

$\mathrm{RK}_{\mathrm{ij}}=$ Degree of the relative importance of the $\mathrm{jth}$ criterion in the choice of the $\mathrm{i}$ decision.

$\mathrm{TKK}_{\mathrm{j}}=$ Degree of importance of the $\mathrm{j}^{\text {th }}$ decision criteria $\mathrm{TKKj}>0$; integer.

$\mathrm{n}=$ Number of decision choices.

$\mathrm{m}=$ Number of decision criteria.

Sorting the Total Value (TN) that has been calculated. The greater the alternative Total Value (TN), the higher the priority order.

\section{Performance Evaluation}

Performance is an achievement achieved by employees in doing work in the organization. Performance evaluation is an assessment in the organization of the performance of employees who have done to improve organizational productivity. This is done because performance is closely related to productivity [3].

\section{Temporary Employees}

Temporary Employees are a type of human resource in the organization who does not have long-term prospects in the organization and refers to work that depends on a limited duration [6]. Temporary Employees in the District Court of Prabumulih consist of three types, namely Security guards, Drivers, and Servants.

\section{Results and Discussion}

\section{Application of Exponential Comparison Method}

The first step is to arrange alternatives to be chosen. Currently, the author is in the process of taking data at the District Court of Prabumulih. So, in this paper, the author uses sample data that has been known by the District Court of Prabumulih. The alternatives are described in the following Table 1:

Table 1. The alternate value of each criterion

\begin{tabular}{llllllll}
\hline & Criteria & & & & & \\
\cline { 2 - 7 } Alternative & $\begin{array}{l}\text { Willingness } \\
\text { Learning }\end{array}$ & Awareness & Discipline & $\begin{array}{l}\text { Self } \\
\text { Management }\end{array}$ & Communication & $\begin{array}{l}\text { Responsibility } \\
\text { and } \\
\text { Behavior }\end{array}$ \\
\hline Mita & Very Good & Medium & Medium & Good & Good & Good & Good \\
Permata & Low & Low & Low & Medium & Good & Medium & Good \\
Ria & Very Good & Good & Good & Good & Good & Very Good & Good \\
Iqbal & Medium & Medium & Medium & Good & Good & Medium & Good \\
Salan & Good & Very Low & Low & Medium & Good & Good & Good \\
\hline
\end{tabular}

Table 1 lists the alternatives to be chosen in evaluating the performance of temporary employees in the District Court of Prabumulih. Table 1 contains the names of temporary employees and the values obtained are based on seven criteria. The data obtained from the results of the interview.
The second step is to determine the criteria or relative comparison of decision criteria that are important to be evaluated using a certain scale based on the wishes of the decision-maker. The Criteria are described in the following Table 2:

Table 2. Criteria for evaluating temporary employees performance

\begin{tabular}{llll}
\hline Criteria Code & Criteria & Sub Criteria & Weight \\
\hline \multirow{3}{*}{$\mathrm{C}_{1}$} & & Very Good & 5 \\
& \multirow{3}{*}{ Willingness Learning } & Good & 4 \\
& & Medium & 3 \\
& & Low & 2 \\
& & Very Low & 1 \\
\hline $\mathrm{C}_{2}$ & \multirow{3}{*}{ Awareness } & Very Good & 5 \\
& & Good & 4 \\
& & Medium & 3 \\
& & Low & 2 \\
$\mathrm{C}_{3}$ & Discipline & Very Low & 1 \\
& & Very Good & 5 \\
& & Good & 4 \\
\hline
\end{tabular}




\begin{tabular}{|c|c|c|c|}
\hline & & Low & 2 \\
\hline & & Very Low & 1 \\
\hline \multirow{5}{*}{$\mathrm{C}_{4}$} & \multirow{5}{*}{ Self Management } & Very Good & 5 \\
\hline & & Good & 4 \\
\hline & & Medium & 3 \\
\hline & & Low & 2 \\
\hline & & Very Low & 1 \\
\hline \multirow{5}{*}{$\mathrm{C}_{5}$} & \multirow{5}{*}{ Communication } & Very Good & 5 \\
\hline & & Good & 4 \\
\hline & & Medium & 3 \\
\hline & & Low & 2 \\
\hline & & Very Low & 1 \\
\hline \multirow{5}{*}{$\mathrm{C}_{6}$} & \multirow{5}{*}{ Responsibility } & Very Good & 5 \\
\hline & & Good & 4 \\
\hline & & Medium & 3 \\
\hline & & Low & 2 \\
\hline & & Very Low & 1 \\
\hline \multirow{5}{*}{$\mathrm{C}_{7}$} & \multirow{5}{*}{ Ethics and Behavior } & Very Good & 5 \\
\hline & & Good & 4 \\
\hline & & Medium & 3 \\
\hline & & Low & 2 \\
\hline & & Very Low & 1 \\
\hline
\end{tabular}

Table 2 contains the criteria used in evaluating the performance of temporary employees in the District Court of Prabumulih. These criteria were obtained from interviews with the District Court of Prabumulih. These criteria are Willingness Learning, Awareness, Discipline, Self-Management, Communication, Responsibility, Ethics, and Behavior. Each criterion has sub-criteria and weights.
The third step is to determine the relative importance of each decision criterion. Determination of the weight is set on each criterion to indicate the level of importance of a criterion. The Weights important are described in the following Table 3:

Table 3. The weight of importance of each criterion

\begin{tabular}{|c|c|c|c|c|}
\hline Criteria Code & Criteria & Sub Criteria & Weight & $\begin{array}{l}\text { Weights } \\
\text { important }\end{array}$ \\
\hline \multirow{5}{*}{$\mathrm{C} 1$} & \multirow{5}{*}{ Willingness Learning } & Very Good & 5 & \multirow{5}{*}{4} \\
\hline & & Good & 4 & \\
\hline & & Medium & 3 & \\
\hline & & Low & 2 & \\
\hline & & Very Low & 1 & \\
\hline \multirow{5}{*}{$\mathrm{C} 2$} & \multirow{5}{*}{ Awareness } & Very Good & 5 & \multirow{5}{*}{4} \\
\hline & & Good & 4 & \\
\hline & & Medium & 3 & \\
\hline & & Low & 2 & \\
\hline & & Very Low & 1 & \\
\hline \multirow{5}{*}{$\mathrm{C} 3$} & \multirow{5}{*}{ Discipline } & Very Good & 5 & \multirow{5}{*}{5} \\
\hline & & Good & 4 & \\
\hline & & Medium & 3 & \\
\hline & & Low & 2 & \\
\hline & & Very Low & 1 & \\
\hline \multirow{5}{*}{$\mathrm{C} 4$} & \multirow{5}{*}{ Self-Management } & Very Good & 5 & \multirow{5}{*}{4} \\
\hline & & Good & 4 & \\
\hline & & Medium & 3 & \\
\hline & & Low & 2 & \\
\hline & & Very Low & 1 & \\
\hline \multirow{5}{*}{$\mathrm{C} 5$} & \multirow{5}{*}{ Communication } & Very Good & 5 & \multirow{5}{*}{4} \\
\hline & & Good & 4 & \\
\hline & & Medium & 3 & \\
\hline & & Low & 2 & \\
\hline & & Very Low & 1 & \\
\hline \multirow{2}{*}{ C6 } & \multirow{2}{*}{ Responsibility } & Very Good & 5 & \multirow{2}{*}{5} \\
\hline & & Good & 4 & \\
\hline
\end{tabular}




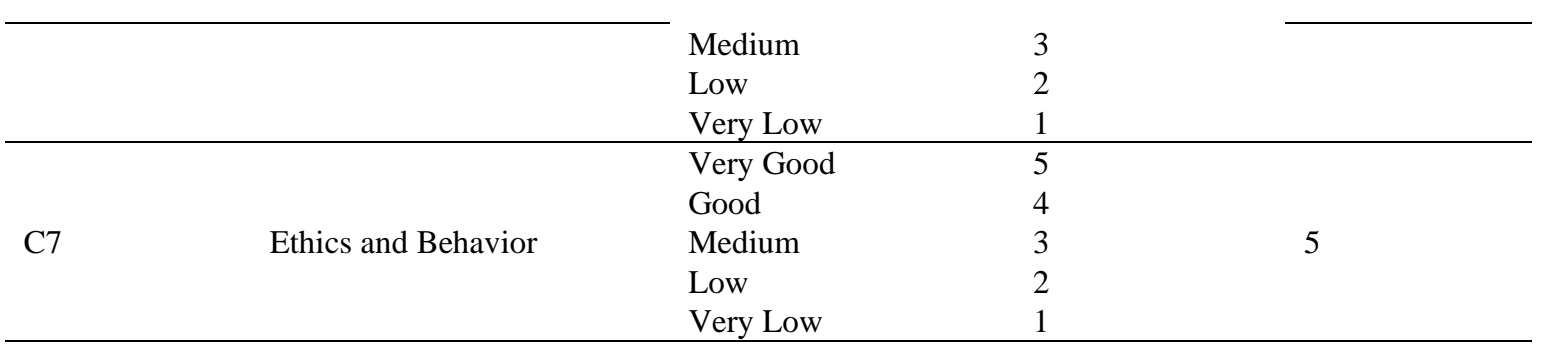

Table 3 contains information about the Weights important of each criterion. The Weights important were obtained from the results of interviews with the Head of the Personnel Subdivision and the Administrative Organization of the District Court of Prabumulih.
The fourth step is to Assess all alternatives on each criterion in the form of a total score of each alternative. The alternatives are described in the following Table 4:

Table 4. Alternative value conversions

\begin{tabular}{llllllll}
\hline \multirow{2}{*}{ Alternative } & \multicolumn{7}{c}{ Criteria } \\
\cline { 2 - 8 } & $\mathrm{C}_{1}$ & $\mathrm{C}_{2}$ & $\mathrm{C}_{3}$ & $\mathrm{C}_{4}$ & $\mathrm{C}_{5}$ & $\mathrm{C}_{6}$ & $\mathrm{C}_{7}$ \\
\hline Mita & 5 & 3 & 3 & 4 & 4 & 4 & 4 \\
Permata & 2 & 2 & 2 & 3 & 4 & 3 & 4 \\
Ria & 5 & 4 & 4 & 4 & 4 & 5 & 4 \\
Iqbal & 3 & 3 & 3 & 4 & 4 & 3 & 4 \\
Salan & 4 & 1 & 2 & 3 & 4 & 4 & 4 \\
\hline
\end{tabular}

The alternative data obtained from the District Court of Prabumulih are converted into a number weight based on table 2 . The results of the conversion are described in table 4 above.

The fifth step is to calculate the Total Value (TN) of each alternative using equation 1 .

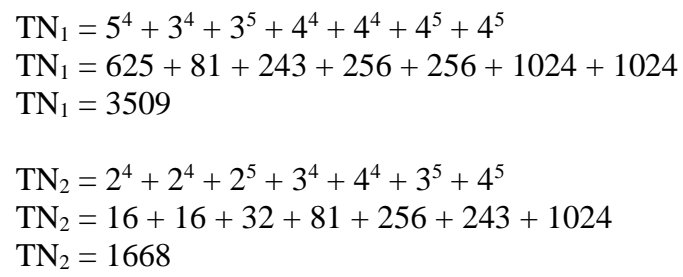

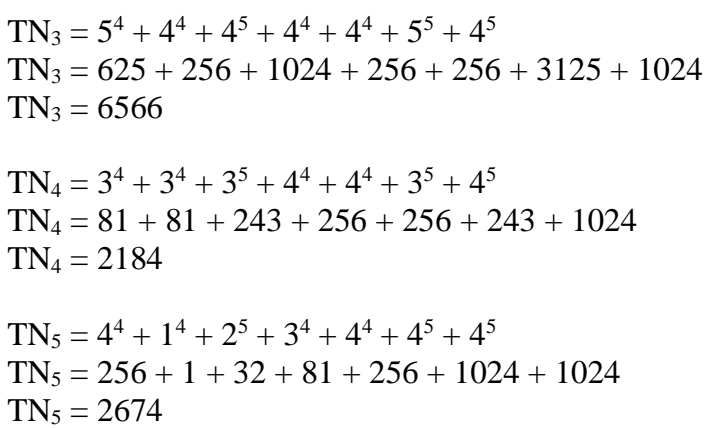

The sixth step is Sorting the Total Value (TN) that has been calculated. The greater the alternative Total Value (TN), the higher the priority order. The priority order is described in the following Table 5:

Table 5. The priority order

\begin{tabular}{ccc}
\hline Ranking & Alternative & Total Value (TN) \\
\hline 1 & Ria & 6566 \\
2 & Mita & 3509 \\
3 & Salan & 2674 \\
4 & Iqbal & 2184 \\
5 & Permata & 1668 \\
\hline
\end{tabular}

Based on the table, it can be seen that Ria has the highest total value. While Permata has the lowest total value. The results of the table can be a management decision support at the District Court of Prabumulih in deciding whether or not contracts with temporary employees.

\section{CONCLUSION}

The implementation of the exponential comparison method is one solution that can be used in evaluating the performance of temporary employees to minimize subjectivity and optimize the results of assessment calculations. The total value generated using this method shows a range of priorities large enough so that the results of the priority order become clearer. This can be seen from Table 5, where the table is a priority that has been calculated using the equation and sorted by the highest total value. The results show that Ria received the highest total value of 6566 while Permata received the lowest total value of 1668. The results from the table can support management decisions in the District Court of Prabumulih in deciding whether to continue contracts with temporary employees with the lowest total value or not. 
[4] Marimin, "Application of decision-making techniques in supply chain management," Bogor IPB $\operatorname{Pr}, 2011$.

[1] U. Hafeez, "Impact of Training on Employees Performance ( Evidence from Pharmaceutical Companies in Karachi, Pakistan)," Bus. Manag. Strateg., vol. 6, no. 1, pp. 49-64, 2015.

[2] R. I. Borman and F. Helmi, "Application of Exponential Comparative Method (MPE) in the Decision Support System Scholarship Student Achievement at SMK XYZ," vol. 3, no. 1, pp. 17-22, 2018.

[3] D. Suranti, “Application of Exponential Comparison Method and Simple Additive Weighting Method in Assessment of Agricultural Extension Performance," Sci. J. Informatics, vol. 5, no. No. 2, 2018.
[5] S. Maryana, E. Kurnia, and A. Ruyani, "Webbased application on employee performance assessment using exponential comparison method," IOP Conf. Ser. Mater. Sci. Eng., 2017.

[6] S. Mauno, N. De Cuyper, U. Kinnunen, and M. Ruokolainen, "Work \& Stress : An International Journal of Work, Health \& Organisations The prospective effects of work-family conflict and enrichment on job exhaustion and turnover intentions : comparing long-term temporary vs. permanent workers across three waves," An Int. J. Work. Heal. Organ., vol. 29, no. No. 1, pp. 75-94, 2015. 